\title{
URGENSI MANAJEMEN BUDAYA ORGANISASI SEKOLAH TERHADAP PEMBENTUKAN KARAKTER PESERTA DIDIK
}

\author{
Received: 26-12-2020
}

Revised: 19-01-2021

Accepted: 10-02-2021

Rony

Sekolah Tinggi Agama Islam Al Fithrah Surabaya

Email: rony99arka@gmail.com

\begin{tabular}{l}
\hline \\
\hline $\begin{array}{l}\text { Keywords: School } \\
\text { culture, }\end{array}$ \\
$\begin{array}{l}\text { Management od } \\
\text { Education, Student } \\
\text { character }\end{array}$ \\
\hline
\end{tabular}

\section{Kata Kunci:}

Budaya sekolah, Manajemen

Pendidikan, karakter peserta didik

\begin{abstract}
To improve the quality of human resources (human resources development) in order to be able to keep up with developments in science and technology, people tend to choose quality educational institutions. The quality of education in schools is inseparable from the culture of the school organization which has become a distinct character of education in schools.In addition to functioning as a school identity that differentiates schools from one another, it can be a standard of behavior for school member that influence school members to carry out internalized actions. The development of a strong, intimate, conducive, and responsible school organizational culture will provide various benefits for all school members. Every school member must play an active role in developing and realizing a good school culture.To develop and create a school organizational culture that can shape the character of students is not an easy matter. In addition to several supporting factors that can help the implementation of a good school organizational culture, there are also inhibiting factors that cannot be underestimated, which will cause the implementation of school organizational culture management not to be carried out properly.
\end{abstract}

\begin{tabular}{l} 
Abstrak \\
\hline Untuk meningkatkan kualitas sumber daya manusia agar mampu \\
mengikuti perkembangan ilmu pengetahuan dan teknologi, \\
masyarakat cenderung memilih lembaga pendidikan yang \\
berkualitas. Kualitas sebuah pendidikan di sekolah tidak terlepas \\
dari budaya organisasi sekolah yang menjadi karakter tersendiri \\
pendidikan di sekolah. Selain berfungsi sebagai identitas sekolah \\
yang menjadi pembeda antara sekolah satu dengan lainnya, ia dapat \\
menjadi standar perilaku warga sekolah yang mempengaruhi warga \\
sekolah untuk melaksanakan tindakan yang dihayati. \\
Pengembangan budaya organisasi sekolah yang kuat, intim, \\
kondusif, dan bertanggung jawab akan memberikan berbagai \\
manfaat bagi seluruh warga sekolah. Setiap warga sekolah wajib \\
berperan aktif dalam mengembangkan dan mewujudkan budaya \\
sekolah yang baik. Untuk mengembangkan dan mewujudkan \\
budaya organisasi sekolah yang dapat membentuk karakter peserta \\
didik bukanlah perkara mudah. Selain beberapa faktor pendukung \\
yang dapat membantu pelaksanaan budaya organisasi sekolah yang \\
baik, terdapat pula faktor penghambat yang tidak bisa dianggap \\
sebelah mata, yang akan menyebabkan implementasi manajemen \\
budaya organisasi sekolah tidak dapat terlaksana dengan baik
\end{tabular}




\section{PENDAHULUAN}

Pendidikan merupakan suatu hal penting bagi kehidupan manusia dalam meningkatkan kualitas sumber daya manusia (human resources development) untuk mampu mengikuti perkembangan ilmu pengetahuan dan teknologi. Pendidikan sendiri merupakan usaha sadar dan terencana untuk mewujudkan suasana belajar dan proses pembelajaran agar peserta didik secara aktif mengembangkan potensi dirinya untuk memiliki kekuatan spiritual keagamaan, pengendalian diri, kepribadian, kecerdasan, akhlak mulia, serta keterampilan yang diperlukan dirinya, masyarakat, bangsa dan Negara. Kualitas sebuah pendidikan di sekolah tidak terlepas dari budaya organisasi sekolah yang menjadi karakter tersendiri pendidikan di sekolah. Budaya atau culture biasa diartikan sebagai pikiran, akal budi, adat istiadat, ataupun sesuatu mengenai kebudayaan yang sudah berkembang atau sesuatu yang sudah menjadi kebiasaan yang sukar diubah. ${ }^{1}$ Budaya secara ideal mengkomunikasikan secara jelas pesan-pesan tentang bagaimana melakukan sesuatu atau tindakan dalam berperilaku di sekitar sini ("how we do things around here" $^{\prime \prime} .^{2}$

Budaya organisasi atau budaya sekolah merupakan suatu persepsi bersama yang dianut oleh anggota-anggota organisasi, atau suatu sistem dari makna bersama. Suatu lembaga atau sekolah yang berbudaya kuat akan mempengaruhi ciri khas tertentu sehingga dapat memberikan daya tarik bagi individu untuk bergabung. Setelah itu individu dapat berpikir, bertindak dan berperilaku sesuai dengan nilai-nilai organisasi. ${ }^{3}$

Budaya organisasi di sekolah memiliki kepribadian organisasi yang mempengaruhi cara bertindak individu dalam organisasi (sekolah) yang merujuk pada suatu sistem nilai, kepercayaan dan norma-norma yang diterima secara bersama, serta dilaksanakan dengan penuh kesadaran sebagai perilaku alami yang dibentuk oleh lingkungan yang menciptakan kesamaan pemahaman, baik itu kepala sekolah, guru, staf, maupun peserta didik, yang berakar dari sikap mental, komitmen, dedikasi, dan loyalitas setiap personil lembaga. Menurut Komarudin Hidayat, tanpa budaya sekolah yang bagus, akan sulit melakukan pendidikan karakter bagi anak-anak didik. Jika budaya

1 Kamus Besar Bahasa Indonesia (KBBI), https:// kbbi.web.id/budaya.html., diakses 21 November 2019.

2 Paul D. Sweeney \& Dean B. McFarlin, Organizational Behavior Solutions for Management (New York: McGraw, 2002), 334.

3 Robbins S.P., Perilaku Organisasi (Jakarta: Salemba Empat, 2002), 247. 
organisasi sekolah sudah mapan, siapapun yang masuk dan bergabung di sekolah itu hampir secara otomatis akan mengikuti tradisi yang sudah ada. ${ }^{4}$

Penjelasan di atas menunjukkan bahwa budaya organisasi sekolah memiliki peranan yang sangat penting dalam meningkatkan kualitas sekolah, hal ini berkaitan erat dengan perilaku dan kebiasaan-kebiasaan warga sekolah dalam melakukan penyesuaian dengan lingkungan, serta cara memandang persoalan dan memecahkan masalah di lingkungan sekolah. Budaya organisasi yang positif akan memberi dampak tersendiri dan sejalan dengan pelaksanaan menajemen berbasis sekolah. Budaya positif tersebut antara lain: budaya jujur, budaya saling percaya, budaya bersih, budaya disiplin, budaya baca, budaya kerjasama, budaya memberi teguran dan penghargaan. ${ }^{5}$

Untuk mewujudkan budaya organisasi sekolah yang positif, perlu adanya manajemen budaya organisasi yang baik. Pada hakikatnya upaya tersebut dilakukan untuk meningkatkan performasi (kinerja) sekolah dalam mencapai tujuan-tujuan pendidikan, baik tujuan nasional maupun local institusional. Kepala sekolah dituntun untuk mampu secara maksimal melaksanakan tugas dan fungsinya dalam mengelola berbagai aspek komponen sekolah untuk mencapai tujuan sekolah yang telah dirumuskan. Peserta didik merupakan salah satu bagian yang turut berada di dalamnya, termasuk dalam pembentukan karakter peserta didik. 6

Pembentukan karakter peserta didik sendiri dapat dipengaruhi oleh berbagai hal, mulai dari lingkungan sekolah yang sehat, suasana kekeluargaan, kolaborasi, semangat untuk maju, dorongan bekerja keras, ataupun kultur belajar yang bermutu, semua tercipta melalui budaya organisasi. Budaya organisasi sekolah dapat menimbulkan perilaku buruk, seperti perilaku melanggar nilai-nilai dan norma yang ada, tidak memiliki tujuan untuk maju bersama, budaya tidak disiplin dan lain sebagainya. ${ }^{7}$

Manajemen budaya organisasi sekolah merupakan salah satu upaya untuk mengembangkan karakter positif peserta didik. Manajemen budaya organisasi sekolah dilakukan agar lingkungan sekolah dapat menjadi tempat yang kondusif bagi pengembangan karakter positif peserta didik. Manajemen budaya sekolah yang kondusif untuk pengembangan karakter positif peserta didik dilakukan dengan memperhatikan prinsip-prinsip berkelanjutan, terpadu, konsisten, implementatif, dan menyenangkan. Untuk pengembangan budaya

${ }^{4}$ Komarudin Hidayat, "Membangun Kultur Sekolah" dalam

http://.www.Uinjkt.ac.id/index.php/categorytable1456-html, diakses 9 Januari 2020.

${ }^{5}$ Neprializa, “Manajemen Budaya Sekolah" dalam Manajer Pendidikan, (No.3, Vol. 9, Juli 2015), 419.

${ }^{6}$ Dr. Rohiat, M.Pd., Manajemen Sekolah, (Bandung: PT. Refika Aditama, 2010), 31.

7 Albertin Dwi Astuti, Pengaruh Budaya Sekolah Terhadap Karakter Siswa Kelas X Jurusan Tata Boga SMK Negeri 3 Klaten (Skripsi. Universitas Negeri Yogyakarta, 2015), 5. 
sekolah diperlukan empat tahapan yaitu perencanaan program, sosialisasi, pelaksanaan program, dan evaluasi program. ${ }^{8}$

Setiap sekolah harus mempunyai visi dan misi sebagai langkah untuk menciptakan budaya organisasi sekolah. Namun yang sering dilupakan adalah bahwa setiap sekolah telah memiliki budaya organisasi yang di dalamnya terdapat seperangkat nilai-nilai, kepercayaan, dan kebiasaan yang sudah mendarah daging. Sehingga peningkatan kualitas sekolah atau mutu pendidikan secara konvensional selama ini senantiasa bertumpu pada manajemen peningkatan kualitas proses belajar mengajar serta manajemen dalam aspek kepemimpinannya saja, namun kurang menyentuh pada aspek budaya organisasi sekolah. Hal tersebut sangat disayangkan, padahal budaya organisasi sekolah yang positif dapat menciptakan budaya mutu di sekolahsekolah, seperti budaya yang selalu mendukung keunggulan, budaya kedisiplinan, budaya kebersamaan, dan budaya-budaya lainnya yang berorientasi pada mutu pendidikan yang baik dan positif. Selain itu, budaya organisasi yang positif juga sangat mendukung peningkatan motivasi dan prestasi warga sekolah. ${ }^{9}$

Dapat dipahami bahwa faktor yang menyebabkan buruknya budaya organisasi sekolah adalah rendahnya manajemen sekolah dalam pelaksanaan budaya organisasi. Sangat besar kemungkinan di berbagai sekolah, pada dasarnya memiliki budaya organisasi sekolah yang baik tetapi pada pelaksanaan manajemen sekolahnya kurang maksimal untuk pengembangan budaya organisasi. Misalnya sekolah ingin menerapkan budaya disiplin dalam menjaga kebersihan dengan membuang sampah pada tempatnya, tetapi sekolah tidak menyediakan tempat sampah, tentu peserta didik akan membuang sampah disembarang tempat karena belum tersediannya tempat. Ataupun jika tempat sampah telah tersedia namun tidak ada pengarahan serta konsekuensi bagi yang melanggar dalam pelaksanaan menjaga kebersihan tesebut, maka dapat dipastikan peserta didik tidak akan selalu membuang sampah pada tempatnya, dan tentu karakter disiplin yang ingin diterapkan tidak akan terlaksana dengan baik.

Kondisi tersebut terjadi karena sekolah belum memahami dan terampil dalam merencanakan, melaksanakan pengembangan, dan mengukur efektivitas pengembangan budaya sekolah. Berdasarkan uraian tersebut, maka sangatlah perlu untuk melaksanakan manajemen budaya organisasi sekolah, terutama dalam pembentukan karakter peserta didik. ${ }^{10}$

8 Neprializa, “Manajemen Budaya......, 420.

${ }_{9}$ Dwi Anto, Budaya Sekolah di SMK Muhammadiyah 1 Playen Kabupaten Gunung Kidul Yogyakarta (Skripsi. Universitas Negeri Yogyakarta, 2013), 4.

10 Neprializa, “Manajemen Budaya......, 420. 
Dengan mengenali manajemen budaya organisasi sekolah dapat dilakukan tindakan untuk perbaikan mutu sekolah terutama dalam membentuk karakter peserta didik. Saat ini pendidikan karakter menjadi sangat penting karena semakin menurunnya nilai moral dan etika peserta didik dan semakin maraknya penyimpangan sosial serta kenakalan pelajar, seperti mencontek, malas belajar, bolos sekolah, bullying dan lain sebagainya. Dengan dilakukannya pembentukan karakter peserta didik diharapkan dapat menghasilkan generasi muda yang berkarakter baik dan berbudi pekerti luhur, seperti halnya dalam UndangUndang Republik Indonesia Nomor 20 Tahun 2003 tentang Sistem Pendidikan Nasional, yang di dalamnya menjelaskan pula tentang fungsi dari pendidikan selain untuk mengembangkan kemampuan peserta didik berfungsi juga untuk membentuk watak atau karakter peserta didik. Peserta didik yang berkarakter dan berbudi pekerti luhur diharapkan mampu membangun peradaban bangsa yang bermartabat. ${ }^{11}$

Sebuah karakter tidak bisa diajarkan lewat lisan ataupun tulisan semata, perlu adanya pengembangan karakter secara optimal. Namun tidak semua lembaga dapat melakukan itu, banyak sekolah yang memiliki visi dan misi untuk menanamkan pendidikan karakter pada peserta didik tetapi pada kenyataannya di lapangan pendidikan sekolah hanya memberikan pembelajaran materi saja. Upaya yang tepat dalam upaya pembentukan karakter peserta didik adalah melalui manejemen budaya organisasi sekolah, dengan adanya manajemen budaya organisasi sekolah. Hal tersebut tentunya tidak lepas dari peran kepala sekolah, staf, serta para guru di sekolah dalam menerapkan budaya organisasi yang baik. ${ }^{12}$

Maka dari itu, apabila sekolah memiliki budaya organisasi yang baik dan didukung dengan manajemen budaya organisasi yang baik maka dampak yang dihasilkan tentu akan baik. Tetapi jika budaya organisasi sekolah yang baik namun tidak didukung oleh manajemen budaya organisasi yang baik pula maka dampak yang dihasilkan bisa baik, bisa juga tidak. Apalagi jika budaya organisasi yang dimiliki oleh sekolah buruk dan ditambah dengan manajemen budaya organisasi sekolah yang juga buruk sudah dapat dipastikan dampak yang dihasilkan tentu akan buruk. ${ }^{13}$

${ }^{11}$ Albertin Dwi Astuti, Pengaruh Budaya..., 3.

12 Ibid, 5.

${ }^{13}$ Dwi Anto, Budaya Sekolah di SMK...(Skripsi. Universitas Negeri Yogyakarta, 2013), 5. 


\section{PEMBAHASAN}

\section{Manajemen Budaya Organisasi Sekolah}

Kata manajemen berasal dari Bahasa Latin, yaitu dari asal "manus" yang berarti tangan dan "agree" yang berarti melakukan. Manajemen dalam bahasa Inggris artinya to "manage", dengan kata benda "management", dan "manager" untuk orang yang melakukan kegiatan manajemen. Akhirnya, "management" diterjemahkan kedalam Bahasa Indonesia yang berarti mengatur atau mengelola. ${ }^{14}$ Menurut George R. Terry dan Leslie W. Rue menyatakan bahwa manajemen adalah suatu proses atau kerangka kerja, yang melibatkan bimbingan atau pengarahan suatu kelompok orang-orang kearah tujuan organisasional atau maksud-maksud yang nyata. ${ }^{15}$ Sedangkan James A. F. Stoner menyatakan bahwa manajemen adalah suatu proses perencanaan, pengorganisasian, pengarahan, dan pengawasan usaha-usaha para anggota organisasi dan penggunaan sumber daya-sumber daya organisasi lainnya agar mencapai tujuan organisasi yang telah di tetapkan. ${ }^{16}$

Terdapat beberapa fungsi dalam manajemen. Masing-masing tidak dapat dipisahkan satu sama lain. Fungsi tersebut adalah:

a. Perencanaan merupakan fungsi pertama, terpenting di antara fungsi manajemen yang lainnya dan sebagai pedoman yang dipakai dasar kemana tujuan organisasi dan bagaimana cara pencapain tujuan organisasi. Perencanan pada hakekatnya merupakan proses pengambilan keputusan yang dipakai sebagai dasar bagi kegiatan atau aktivitas di masa datang dalam rangka mencapai tujuan. Proses ini memerlukan pemikiran tentang apa yang akan dikerjakan, mengapa, bagaimana, dan di mana suatu kegiatan dilakukan serta siapa yang terlibat dan bertanggung jawab dalam pekerjaan tersebut. Atau istilah lain perencanaan dirumuskan dalam rangka menjawab $5 \mathrm{~W}$ dan $1 \mathrm{H}$.

b. Pengorganisasian merupakan usaha untuk menyusun komponen utama organisasi sedemikian rupa sehingga dapat dipakai sebagai sarana untuk mencapai tujuan organisasi secara efektif dan efesien. Dalam pengorganisasian diharapkan tejadi hubungan- hubungan di antara masing- masing komponen organisasi. Dengan, demikian fungsi pengorganisasian dapat dikatakan sebagai proses menciptakan hubungan antara berbagai fungsi, personalian dan faktor-faktor fisik lainnya agar semua pekerjaan dapat di lakukan secara efektif dan efesien.

${ }^{14}$ Husaini Usman., Manajemen Teori Praktik \& Riset Pendidikan (Jakarta: PT Bumi Aksara, 2008), 4.

${ }^{15}$ George R. Terry dan Leslie W. Rue, Dasar - Dasar Manajemen (Jakarta: Bumi Aksara, 1992), 1.

16T. Handoko., Manajemen (Yogyakarta: BPFE, 1998), 11. 
c. Pengarahan merupakan fungsi yang sangat kompleks, disamping menyangkut hubungan manusia juga menyangkut perilaku manusia yang beranekaragam serta berkaitan dengan sumber daya lain yang dimiliki. Oleh karena itu, fungsi pengarahan menunjukkan aktivitas-aktivitas seperti penyusunan staf, koordinasi, perintah, kepemimpinan dan pelaporan. Dalam pengarahan pimpinan harus memperhatikan kepentingan individu, kelompok, dan organisasi.

d. Pengendalian, Manajemen yang baik memerlukan pengendalian yang efektif. Pengendalian diperlukan utuk memastikan bahwa aktivitas atau kegiatan berjalan sesuai dengan direncanakan. Perencanaan dan pengendalian merupakan fungsi yang berpasangan, artinya pengendalian yang baik memerlukan perencanaan yang baik memerlukan pengendalian. ${ }^{17}$

Dari berbagai pendapat tentang manajemen serta fungsi manajemen diatas dapat disimpulkan bahwa manajemen berkaitan dengan suatu proses perencanaan, pengorganisasian, kepemimpinan, pengendalian dan evaluasi yang di dalamnya terdapat upaya dari anggota organisasi untuk mencapai tujuan yang telah ditetapkan bersama secara efektif dan efesien. ${ }^{18}$

\section{Fungsi, Jenis dan Karakter Budaya Organisasi Sekolah}

Kata budaya diadaptasi dari bahasa Inggris, yaitu culture dan dalam bahasa Latin, colore. Secara harfiyah diartikan sebagai pikiran, akal budi, atau sejumlah pola sikap, keyakinan, dan perasaan tertentu yang mendasari, mengarahkan, dan memberi arti pada tingkah laku seseorang dalam suatu masyarakat. ${ }^{19}$ Budaya menurut Soekanto yang merupakan kata Sansekerta "budhayyah" dengan bentuk jamak "budhi" yang berarti akal. Dengan demikian budaya dapat di artikan sebagai hal-hal yang berhubungan dengan akal dan budi. Sementara Selo Sumarjan merumuskan budaya sebagai semua hasil karya yang menghasilkan teknologi dan kebudayaan kebendaan maupun kebudayaan jasmaniah dalam upaya menguasai alam sekitar, sebagai rasa meliputi jiwa manusia, dan cipta masyarakat yang mewujudkan segala kaidahkaidah dan nilai-nilai kemasyarakatan dalam arti yang luas. Di dalamnya termasuk ideologi, kebatinan, kesenian dan segala pengetahuan manusia. ${ }^{20}$

Pengertian budaya organisasi sekolah sendiri terdapat beberapa definisi. Short dan Greer mendefinisikan bahwa budaya sekolah merupakan keyakinan,

\footnotetext{
17Tim FKIM UMS, Manajemen Pendidikan (Surakarta: Muhammadiyah University Press, 2004), 5-14.

${ }^{18 N a n a n g ~ F a t t a h ., ~ L a n d a s a n ~ M a n a j e m e n ~ P e n d i d i k a n ~(B a n d u n g: ~ P T ~ R e m a j a ~ R o s d a k a r y a, ~ 2000), ~} 1$.

19 Mhd. Rusydi, Customer Excellence (Ypgyakarta: Gosyen Publishing, 2017), 192.

20 Soerjono Soekanto, Sosiologi Suatu Pengantar (Jakarta: Rajawali, 1983), 166-167.
} 
kebijakan, norma, dan kebiasaan dalam sekolah yang dapat dibentuk, diperkuat, dan dipelihara melalui pimpinan dan guru-guru di sekolah. ${ }^{21}$ Deal dan Peterson menyatakan bahwa budaya sekolah adalah sekumpulan nilai yang melandasi perilaku, tradisi, kebiasaan keseharian, dan simbol-simbol yang di praktikkan oleh kepala sekolah, guru, petugas administrasi, peserta didik, dan citra sekolah tersebut di masyarakat luas. ${ }^{22}$ Budaya sekolah bisa juga disebut dengan kultur sekolah, karena selalu menentukan bagaimana orang bekerja dan beraksi. Dengan arti lain istilah budaya sekolah merupakan pemindahan norma, nilai, dan tradisi dari satu generasi ke generasi berikutnya, sehingga budaya sekolah dapat mengalami perubahan baik secara sengaja maupun tanpa disengaja. ${ }^{23}$

Sedangkan menurut Zamroni, budaya organisasi di sekolah atau budaya sekolah adalah pola nilai-nilai, prinsi-prinsip, tradisi-tradisi dan kebiasaankebiasaan yang terbentuk dalam perjalanan panjang sekolah, dikembangkan sekolah dalam jangka waktu yang lama dan menjadi pegangan serta diyakini oleh seluruh warga sekolah sehingga mendorong muncul sikap dan perilaku warga sekolah. Begitu pentingnya sebuah budaya di dalam sekolah, maka sekolah yang merupakan suatu organisasi, harus memiliki: a) Kemampuan untuk hidup, tumbuh berkembang dan melakukan adaptasi dengan berbagai lingkungan yang ada, dan b) integrasi internal yang memungkinkan sekolah untuk menghasilkan individu atau kelompok yang memiliki sifat positif. ${ }^{24}$ Dari beberapa pendapat di atas dapat disimpulkan bahwa budaya organisasi sekolah merupakan norma perilaku bersama warga sekolah yang terdiri dari adat/istiadat, kebiasaan yang positif maupun negatif, yang telah dijalankan oleh sekolah dan sudah menjadi kebiasaan bahkan menjadi pegangan oleh seluruh warga sekolah sehingga mendorong untuk memunculkan sikap dan perilaku seluruh warga sekolah.

Pada dasarnya fungsi dari budaya sekolah adalah sebagai identitas sekolah yang merupakan ciri khas sekolah sehingga menjadi pembeda antar sekolah. Identitas tersebut berupa kurikulum, tata tertib, logo sekolah, ritualritual, pakaian seragam dan sebagainnya. Tidaklah muda dalam menciptakan budaya organisasi sekolah, perlu melalui berbagai proses yang tidak singkat. Biasanya budaya organisasi sekolah terbentuk dari visi dan misi sekolah yang

${ }^{21}$ Zuchdi, Pendidikan Karakter dalam Perspektif Teori dan Praktik (Yogyakarta: UNY Press, 2011), 133.

22 Supardi, Sekolah Efektif: Konsep Dasar dan Praktiknya (Jakarta: Raja Grafindo Persada, 2015), 221.

${ }^{23}$ Ibid, 11.

24 Zamroni, Pendidikan Demokrasi pada Masyarakat Multikultural (Yogyakarta: Gafin Kalam Utama, 2011), 87. 
selanjutnya dikembangkan sebagai adaptasi lingkungan masyarakat baik internal maupun eksternal. ${ }^{25}$ Menurut Siagian, fungsi budaya organisasi yang menonjol dan penting untuk diaktualisasikan adalah: a) Penentu batas-batas berperilaku, b) Menumbuhkan kesadaran tentang identitas sebagai anggota organisasi, c) Menumbuhkan komitmen, d) Pemeliharaan stabilitas organisasional, e) Sebagai instrumen pengawasan. ${ }^{26}$

Budaya organisasi sekolah yang terpelihara dengan baik mampu menampilkan perilaku iman, taqwa, kreatif dan inovatif yang harus dikembangkan terus-menerus. Dengan begitu budaya sekolah tentu akan memberi dukungan dalam menciptakan identitas sekolah, hal tersebut menunjukkan bahwa budaya memiliki fungsi yang penting dalam sebuah organisasi sekolah. ${ }^{27}$

Nilai (value) merupakan suatu ukuran normatif yang mempengaruhi manusia untuk melaksanakan tindakan yang dihayati. Menurut Surya, nilai merupakan pengalaman yang dimiliki setiap orang yang memungkinkan dia berkembang dan belajar. Dari pengalaman itu, individu mendapatkan patokanpatokan umum untuk bertingkah laku. Misalnya, bagaimana cara berhadapan dengan orang lain, bagaimana menghormati orang lain, bagaimana memilih tindakan yang tepat dalam suatu situasi, dan sebagainya. Patokan-patokan ini cenderung dilakukan dalam waktu dan tempat tertentu. ${ }^{28}$

Menurut Koentjaraningrat, nilai budaya terdiri dari konsepsi-konsepsi yang hidup dalam alam fikiran sebagian besar warga masyarakat mengenai hal-hal yang mereka anggap mulia. Nilai-nilai budaya merupakan nilai-nilai yang disepakati dan tertanam dalam suatu masyarakat, yang mengakar pada suatu kebiasaaan, kepercayaan, simbol-simbol, dan karakteristik tertentu yang dapat dibedakan dengan lainnya serta akan membentuk suatu budaya sekolah. ${ }^{29}$

Pada dasarnya nilai-nilai budaya akan tampak pada simbol- simbol, slogan, motto, visi, misi atau sesuatu yang nampak sebagai acuan pokok suatu lingkungan atau organisasi. Ada tiga hal yang berkaitan dengan nilai-nilai budaya, yaitu: (a) simbol-simbol, slogan atau yang lainnya yang kelihatan kasat mata (jelas); (b) sikap, tingkah laku, gerak gerik yang muncul akibat slogan,

25 Achmad Susanto, Manajemen Peningkatan Kinerja Guru: Konsep, Strategi, dan Implementasi (Jakarta: Kencana, 2016), 195.

26 Sondang P. Siagian, Kiat Meningkatkan Produktivitas Kerja (Jakarta: Rineka Cipta, 2002), 199.

27 Achmad Susanto, Manajemen Peningkatan Kinerja..., 196.

28 Surya, Nilai-Nilai Kehidupan (Kunigan: PGRI PD II Kuningan, 1995), 3-8.

${ }^{29}$ Koentjaraningrat, Kebudayaan Jawa (Jakarta: PN. Balai Pustaka, 1984), 180. 
moto tersebut; dan (c) kepercayaan yang tertanam (believe system) yang mengakar dan menjadi kerangka acuan dalam bertindak dan berperilaku (tidak terlihat). Nilai-nilai budaya itulah yang akan berlaku di budaya sekolah dan akan membentuk sistem budaya serta merupakan konsep mengenai apa yang dianggap bernilai, berharga dan penting dalam hidup. Sehingga dapat berfungsi sebagai suatu pedoman yang memberi arah dan orientasi kepada warga sekolah sendiri. ${ }^{30}$

Dengan demikian, budaya sekolah merupakan salah satu unsur sekolah yang penting dalam mendukung peningkatan prestasi dan mutu suatu sekolah, termasuk nilai-nilai dan norma-norma yang dianut sekolah yang meliputi: visi, misi, tujuan sekolah, ethos kerja, integrasi, norma agama, norma hukum dan norma sosial. 31

\section{Jenis dan Karakteristik Budaya Organisasi Sekolah}

Masing-masing sekolah tentu memiliki jenis budayanya sendiri yang menjadi pembeda antara sekolah satu dengan sekolah lainnya. Dengan adanya perbedaan tersebut, akan memunculkan berbagai jenis budaya sekolah yang diterapkan. Apakah itu baik atau buruk, positif maupun negatif bahkan berkualitas atau tidaknya sebuah sekolah juga dapat dibedakan melalui budaya organisasi sekolahnya. ${ }^{32}$ Jenis-jenis budaya yang perlu untuk dikembangkan oleh sekolah yaitu sebagai berikut:

a) Budaya keagamaan (religious) atau moral spiritual

Menanamkan perilaku atau tata krama yang tersistematis dalam pengamalan ajaran agamanya masing-masing sehingga terbentuk kepribadian dan sikap yang baik (akhlaqul Karimah). Seperti Budaya Salam, Do'a sebelum/sesudah belajar, Do'a bersama, Sholat Berjamaah (bagi yang beragama Islam), peringatan hari besar keagamaan dan kegiatan keagamaan lainnya.

b) Budaya kerjasama (team work)

Menanamkan rasa kebersamaan dan rasa sosial terhadap sesama melalui kegiatan yang dilakukan bersama. Adapun Bentuk Kegiatannya antara lain MOS, Kunjungan Industri, Parents Day, Baksos, Teman Asuh, Sport And Art, Kunjungan Museum, Pentas Seni, Studi banding, Ekskul, Pelepasan

\footnotetext{
30 Naniek Sulistya Wardani, "Pengembangan Nilai-Nilai Budaya Sekolah Berkarakter" dalam Scholaria, (No. 3, Vol.5, September 2015), 14.

31 Fitri Rayani Siregar, "Nilai-Nilai Budaya Sekolah dalam Pembinaan Aktivitas Keagamaan Siswa SD IT Bunayya Padangsidimpuan" dalam Jurnal Pusat Studi Gender dan Anak, (No.1, Vol.1, 2017).

32 Balitbang, Kepemimpinan Transformasional Kepala Sekolah (Jakarta, 2003$), 29$.
} 
Siswa, Seragam Sekolah, Majalah Sekolah, Potency Mapping, Buku Tahunan, PHBN, (Peringatan hari Besar Nasional), dan PORSENI.

c) Budaya kepemimpinan (leadhership)

Menanamkan jiwa kepemimpinan dan keteladanan dari sejak dini kepada peserta didik. Bentuk kegiatannya berupa budaya kerja keras, cerdas dan ikhlas, budaya kreatif; mandiri \& bertanggung jawab, budaya disiplin/TPDS, ceramah umum, upacara bendera, olah raga jumat pagi, studi kepemimpinan siswa, LKMS (Latihan Keterampilan manajemen siswa), disiplin siswa, dan OSIS.

d) Budaya bersih rapi

Kebiasaan hidup yang bersih ini sangatlah Islami, terdapat nilai religius dan nilai medis yang dapat ditemukan dari kebiasaan ini. Untuk nilai religius seperti ucapan dan tingkah laku selalu berasal dari hati yang bersih. Adapaun untuk nilai medis seperti badan dan pakaian yang bersih akan berdampak pada kesehatan otak maupun kesehatan fisik.

e) Budaya cinta tanah air

Budaya cinta tanah air ini merupakan sikap batin yang dilandasi ketulusan dan keikhlasan yang diwujudkan dalam perbuatan demi kemajuandan kejayaan bangsa dan tanah air. Beriman dan bertakwa kepada Tuhan Yang Maha Esa, berbudi pekerti luhur, berkepribadian, mandiri, tangguh, kreatif, terampil, disiplin, beretos kerja, profesional serta budaya sekolah yang mampu menumbuhkan jiwa patriotik dan mempertebal rasa cinta tanah air merupakan budaya cinta tanah air. ${ }^{33}$

f) Budaya belajar

Budaya belajar ini dapat dikatakan bahwa peserta didik harus mencintai belajar dengan mengembangkan pemikiran bahwa peserta didik dapat belajar lebih bermakna jika diberi kesempatan untuk belajar menemukan dan mengontruksi sendiri pengetahuan baru dan keterampilan yang dimiliki.

g) Budaya mutu

Budaya mutu dalam istilah lain dikatakan organitation culture value, yang dijadikan perwujudan dari upaya menerjemahkan visi ke dalam nilai-nilai instrumen yang dapat menjadi pedoman bertingkah laku bagi semua komponen sekolah. sekolah dikatakan memiliki budaya mutu jika kedudukan dalam organisasi diperlakukan sama, keterbukaan antara

${ }^{33}$ Fauzah Lutfania, Pembentukan Karakter Cinta Tanah Air di Sekolah Dasar Negeri Argosari 01 Jabung-Malang (Skripsi. Universitas Negeri Maulana Malik Ibrahim Malang, 2017), 32. 
bawahan dan atasan, terjalinnya hubungan yang harmonis, fokus pada proses, serta tidak ada kejayaan ataupun kegagalan melainkan pembelajaran dari pengalaman. ${ }^{34}$

Selain memiliki jenis budaya organisasi sekolah, setiap sekolah tentu juga memiliki karakteristiknya sendiri. Adapun karakteristik budaya organisasi sekolah antara lain:35

a) Kolegalitas, merupakan budaya yang menimbulkan rasa saling menghormati dan menghargai sesama profesi kependidikan.

b) Eksperimen atau percobaan di sini merupakan percoban dalam menemukan pola kerja yang lebih baik dan diharapkan menjadi milik sekolah, seperti model pembelajaran, serta adanya ide baru atau terjadi penemuan-penemuan.

c) Trust and confidience. Bisa juga diartikan dengan kepercayaan dan keyakinan yang kuat dalam kehidupan suatu profesi. Budaya organisai sekolah yang kondusif akan memberikan kepercayaan berdasarkan adanya kesesuaian antara pernyataan dan perbuatan.

d) Tangible and support. karakteristik budaya sekolah tangible and support merupakan budaya sekolah yang mendukung adanya perbaikan pembelajaran serta pengembangan profesi ataupun keahlian sumber daya manusia yang ada di dalam sekolah.

e) High expectation. Karakteristik budaya sekolah ini adalah dengan memberikan harapan kepada setiap orang untuk dapat memperoleh prestasi tertinggi yang pernah dicapai, didukung, dirayakan ataupun diberikan imbalan atas kemajuan yang diperoleh.

f) Caring, celebration, and humor. Karakteristik ini memiliki arti bahwa budaya organisasi sekolah perlu untuk saling memberi perhatian, saling menghormati, memuji, saling menggembirakan dan tidak saling menjatuhkan.

g) Appreciation and recognation. Setiap sumber daya manusia di sekolah memiliki hak untuk mendapatkan penghargaan atas hasil prestasi yang dicapai, sehingga dengan merasa diperlakukan istimewa maka akan bertindak istimewa pula.

h) Involvement in decision making. Budaya sekolah yang melibatkan para staf turut serta dalam pembuatan keputusan, sehingga segala sesuatunya

${ }^{34}$ Mulyadi, "Pengembangan Budaya Mutu Madrasah Menurut Teori Block Ice Lewin" dalam Jurnal Psikoislamika (No.1, Vol.6, Januari 2009), 107.

35 Achmad Susanto, Manajemen Peningkatan Kinerja..., 193-194. 
menjadi transparan kepada semua staf sekolah sehingga dapat saling mengetahui dan mampu memecahkan masalahnya bersama.

i) Reaching out to the knowledge base atau menjangkau basis pengetahuan, yang berarti bahwa suatu sekolah merupakan tempat pengembangan ilmu secara luas, objektif, proporsional, tempat pengkajian maupun penelitian. Semuanya berlandaskan keilmuannya terlebih dahulu sehingga dapat mengembangkan gagasan maupun konsep baru.

j) Tradition. Memiliki ritual-ritual sendiri atau memelihara tradisi yang sudah berjalan lama dan dianggap baik, yang merupakan budaya dalam lingkungan sekolah dan biasanya sukar untuk ditiadakan. Misalnya seperti, tradisi wisuda, upacara bendera, penghargaan atas jasa atau prestasi dan sebagainya.

k) Honest and open communication. Terpeliharanya kejujuran dan keterbukaan di lingkungan sekolah, karena sekolah merupakan lembaga pendidikan yang seharusnya membentuk manusia yang jujur, cerdas dan terbuka dalam menerima gagasan ataupun pendapat lainnya.

1) Protection of what's important dapat diartikan sebagai melindungi hal yang dianggap penting, hal ini merupakan karakteristik budaya organisasi sekolah yang memelihara dan menjaga rahasia pekerjaan. Budaya yang baik akan mengetahui mana yang perlu dibicarakan dan apa yang harus dirahasiakan.

Jenis dan karakteristik budaya sekolah diatas merupakan landasan yang dapat dijadikan acuan atau indikator untuk menentukan bagaimana budaya organisasi yang diterapkan oleh sebuah sekolah. Secara khusus budaya sekolah sangatlah penting karena dapat menentukan efektivitas hubungan interpersonal setiap warga sekolah. Hal ini berhubungan langsung dengan visi misi sekolah dalam mencapai tujuan yang telah dicanangkan.

\section{Pengembangan Budaya Organisasi Sekolah}

Keberadaan budaya sekolah di dalam organisasi sekolah menjadi peran utama dari segala aktivitas yang dijalankan warga sekolah mulai dari guru, karyawan, peserta didik dan orang tua. Budaya sekolah yang didesain secara terstruktur, sistematis, dan tepat sesuai dengan kondisi sosial sekolahnya, pada akhirnya dapat memberikan kontribusi yang positif bagi peningkatan kualitas sumber daya manusia sekolah dalam menuju sekolah yang berkualitas. ${ }^{36}$

36 Eva Maryamah, "Pengembangan Budaya Sekolah" dalam Tarbawi, (No.02, Vo.2, Desember 2016), 88 . 
Pengembangan budaya yang di sekolah meliputi: pengembangan nilai, pengembangan tataran teknis, pengembangan tataran sosial, pengembangan budaya sekolah di kalangan peserta didik, dan evaluasi budaya sekolah. Adapun pengembangan budaya terkait nilai-nilai di kalangan peserta didik antara lain: keimanan dan ketaqwaan, nilai kebersamaan, nilai saling menghargai, nilai tanggung jawab, keamanan, kebersihan, ketertiban dan keindahan serta hubungan antar peserta didik dengan seluruh warga sekolah. ${ }^{37}$

Adapun pengembangan budaya organisasi sekolah yang kuat, intim, kondusif, dan bertanggung jawab akan memberikan manfaat sebagai berikut: ${ }^{38}$ a) Menjamin kualitas kerja yang lebih baik, b) Membuka seluruh jaringan komunikasi dari segala jenis dan level, baik itu komunikasi vertikal maupun horizontal, c) Lebih terbuka dan transparan, d) Menciptakan kebersamaan dan rasa saling memiliki yang tinggi, e) Meningkatkan solidaritas dan rasa kekeluargaan, f) Jika menemukan kesalahan akan segera dapat diperbaiki dan g) Dapat beradaptasi dengan baik terkadap perkembangan IPTEK. Begitu pentingnya budaya sekolah terhadap keberlangsungan suatu organisasi sekolah, maka setiap warga sekolah wajib berperan aktif dalam mengembangkan dan mewujudkan budaya sekolah yang efektif.

Manajemen budaya organisasi sekolah merupakan proses pembentukan dan pengelolaan budaya organisasi yang meliputi perencanaan, pengorganisasian, pengendalian, pengawasan dan pengevaluasian. Dalam proses tersebut tentu tidak selalu berjalan sesuai apa yang telah direncanakan, pasti ada yang menjadi faktor pendukung dan penghambat dalam penerapannya. 39

Adapun faktor pendukung dalam pelaksanaan manajemen budaya organisasi sekolah adalah a) Bertambahnya jumlah anggota organisasi, 2) Keteladanan pimpinan organisasi, 3) Keyakinan anggota terhadap nilai-nilai yang dianut oleh organisasi, 4) Pendelegasian yang maksimal terhadap prestasi kerja anggota, 5) Pendelegasian yang proporsional dan profesional, 6) Penghargaan yang maksimal terhadap prestasi kerja anggota, 6) Pengembangan kesejahteraan anggota dan 7) Adaptasi dan kemampuan menerima yang mengakar dari anggota terhadap tata kerja dan sistem nilai yang dianut dalam berorganisasi.. ${ }^{40}$

37 Yusuf Syamsu, Psikologi Perkembangan Anak (Bandung: Remaja Rosdakarya, 2008), 129.

38 Eva Maryamah, "Pengembangan Budaya Sekolah"......, 86.

39 Moh. Pabundu Tika, Budaya Organisasi dan Peningkatan Kinerja Perusahaan (Jakarta: Bumi Aksara, 2006), 150.

${ }^{40}$ Hikmat, Manajemen Pendidikan (Bandung: CV. Pustaka Setia, 2009), 230. 
Adapun faktor yang menjadi penghambat pelaksanaan manajemen budaya organisasi sekolah antara lain: ${ }^{41}$

a) Manajemen yang terlalu longgar, yang menyebabkan tidak adanya komitmen serius di antara warga sekolah

b) Tidak tepatnya sistem reward dan punishement

c) Kurangnya penghayatan terhadap nilai-nilai dan keyakinan budaya organisasi sekolah sehingga kurang maksimalnya pelaksanaan budaya organisasi sekolah yang dilakukan oleh warga sekolah.

d) Kurangnya sosialisasi dan pengarahan manajemen, yang akan mengakibatkan komunikasi antara warga sekolah dan orang tua/wali murid terhambat sehingga penyampaian terkait budaya sekolah kurang maksimal dalam penerapannya

e) Tidak tepatnya perencanaan program dan kegiatan operasional, sehingga tujuan yang diinginkan tidak tercapai dengan jelas

f) Para pimpinan tidak menghargai warga sekolah disemua tingkat yang bertanggung jawab dan cenderung melumpuhkan inisiatif dan inovasi serta cenderung sentralisasi

g) Kurang menghargai inisiatif perseorangan untuk melakukan perubahan-perubahan budaya yang bermanfaat.

Selain yang tersebut di atas, terdapat pula pendapat lain tentang faktor yang mempengaruhi terlaksananya budaya sekolah. faktor pendukung yang dapat menjadikan manajemen budaya organisasi sekolah berjalan dengan baik antara lain: sarana dan prasarana, lingkungan yang kondusif, dan peran serta orang tua/wali murid. Adapun faktor penghambatnya dapat berasal dari guru yang kurang kompeten dan profesional, peserta didik itu sendiri dan manajemen yang berjalan di sekolah.

Faktor yang mempengaruhi manajemen budaya organisasi sekolah, baik itu faktor pendukung maupun penghambat, nantinya merupakan faktor penentu berjalan tidaknya manajemen budaya organisasi sekolah, jika dapat mengolahnya dengan baik dan memiliki komitmen yang kuat dalam pengelolaannya, maka akan tercipta budaya sekolah yang kuat pula dan dihayati oleh seluruh warga sekolah.

\section{Karakter Peserta Didik}

Menurut Kamus Besar Bahasa Indonesia, karakter adalah sifat-sifat kejiwaan, akhlak, budi pekerti yang membedakan seseorang dari orang

${ }^{41}$ Moh. Pabundu Tika, Budaya Organisasi..., 151. 
lainnya. Karakter merupakan nilai-nilai unik yang terpateri dalam diri dan terejawantahkan dalam perilaku. Karakter secara koheren memancar dari hasil pola pikir, olah hati, olah rasa dan karsa serta olah raga seseorang atau sekelompok orang. ${ }^{42}$

Karakter dalam bahasa Inggris adalah "character", yang berasal dari bahasa Yunani character atau charassain yang berarti membuat tajam, membuat dalam. Dalam kamus Poerwardarminta, karakter diartikan sebagai tabiat, watak, sifatsifat kejiwaan, akhlak atau budi pekerti yang membedakan seseorang dengan orang lain. Seperti hal-hal yang meliputi perilaku, kebiasaan, kesukaan, ketidaksukaan, kemampuan, potensi, nilai- nilai, dan pola-pola pikiran. ${ }^{43}$

Menurut Scerenko, karakter adalah ciri-ciri yang membentuk dan membedakan ciri pribadi, ciri etis dan kompleksitas mental dari seseorang. ${ }^{4}$ Sedangkan menurut Winnie, istilah karakter memiliki dua pengertian. Pertama, ia menunjukkan bagaimana perilaku buruk. Jika apabila seseorang beperilaku jujur, suka menolong, tentulah orang tersebut termasuk perwujudan dari karakter mulia. Kedua, istilah karakter erat kaitannya dengan personality. Seseorang baru bisa dikatakan sebagai orang yang berkarakter apabila tingkah lakunya sesuai dengan kaidah moral seseorang, berperilaku tidak jujur, kejam atau rakus, tentu orang tersebut memanifestasikan. ${ }^{45}$

Pengertian-pengertian diatas, jika diambil kesimpulan tentang pengertian karakter dapat dipahami bahwa karakter merupakan nilai-nilai secara keseluruhan perilaku manusia yang meliputi seluruh aktivitas kehidupan, baik yang berhubungan dengan Tuhan, diri sendiri, sesama manusia maupun dengan lingkungan yang terwujud dalam pikiran, sikap, perasaan, perkataan, dan perbuatan berdasarkan norma-norma agama, hukum, tata krama, budaya, dan adat istiadat.

Kementerian Pendidikan Nasional dan Kebudayaan telah merumuskan 18 nilai karakter yang akan ditanamkan dalam diri peserta didik sebagai upaya membangun karakter bangsa. Nilai karakter yang berjumlah 18 tersebut telah disesuaikan dengan kaidah-kaidah ilmu pendidikan secara umum, sehingga lebih implementatif untuk diterapkan dalam praktis pendidikan. Adapun 18

42 Syamsul Kurniawan, Pendidikan Karakter Konsepsi $\mathcal{E}$ Implementasi Secara Terpadu di Lingkungan Keluarga, Sekolah, Perguruan Tinggi \& Masyarakat (Yogyakarta: Ar-Ruzz Media: 2013), 29.

43 Abdul Majid dan Dian Andayani, Pendidikan Karakter Perspektif Islam (Bandung: PT. Remaja Rosdakarya, 2011), 42.

44 Muchlas Samani dan Hariyanto, Konsep dan Model Pendidikan Karakter (Bandung: PT. Remaja Rosdakarya Offset, 2013), 42.

${ }^{45}$ Heri Gunawan, Pendidikan Karakter Konsep dan Implementasi (Bandung: Alfabeta, 2012), 2. 
nilai yang dikembangkan dalam karakter peserta didik adalah sebagai berikut: 46

a) Religius, Karakter religius merupakan sikap dan perilaku yang patuh dalam melaksanakan ajaran agama yang dianutnya, toleransi terhadap pelaksanaan ibadah agama lain, dan hidup rukun dengan pemeluk agama lain.

b) Jujur, Jujur merupakan perilaku yang didasarkan pada upaya menjadikan dirinya sebagai orang yang selalu dapat dipercaya dalam perkataan, tindakan, dan pekerjaan.

c) Toleransi merupakan sikap dan tindakan yang menghargai perbedaan agama, suku, etnis, pendapat, sikap dan tindakan orang lain yang berbeda dari dirinya. Seseorang yang memiliki karakter toleransi, dia akan mampu menerima perbedaan orang lain, tidak akan memaksakan kehendak, tidak menghakimi orang lain berdasarkan penampilan atau latar belakang, mampu bersikap lemah lembut dan merasa iba kepada orang yang kurang berundung darinya.

d) Disiplin, Karakter disiplin sendiri merupakan tindakan yang menujukkan perilaku tertib dan patuh pada berbagai ketentuan dan peraturan.

e) Kerja keras merupakan Perilaku yang menunjukkan upaya sungguhsungguh dalam mengatasi berbagai hambatan belajar dan tugas, serta menyelesaikan tugas dengan sebaik-baiknya.

f) Kreatif, Berfikir dan melakukan sesuatu untuk menghasilkan cara atau hasil baru dari sesuatu yang telah dimiliki.

g) Mandiri merupakan sikap dan perilaku yang tidak mudah tergantung pada orang lain dalam menyelesaikan tugas-tugas.

h) Demokratis memiliki cara berfikir, bersikap, dan bertindak yang menilai sama hak dan kewajiban dirinya dan orang lain.

i) Rasa ingin tahu merupakan sikap dan tindakan yang selalu berupaya untuk mengetahui lebih mendalam dan meluas dari sesuatu yang dipelajarinya, dilihat, dan didengar.

j) Semangat kebangsaan. Karakter ini merupakan karakter cara berfikir, bertindak dan berwawasan yang menempatkan kepentingan bangsa dan Negara di atas kepentingan diri dan kelompoknya.

46 Muhammad Yaumi, Pendidikan Karakter Landasasan, Pilar \& Implementasi, (Jakarta: Prenadamedia Group, 2014), 85-114. 
k) Cinta tanah air adalah cara berfikir, bersikap, dan berbuat yang menunjukkan kesetiaan, kepedulian, dan penghargaan yang tinggi terhadap bangsa, lingkungan fisik, sosial, budaya, ekonomi, dan politik bangsa. Karakter cinta tanah air harus ditanamkan sejak dini kepada peserta didik sehingga mereka bisa memiliki rasa cinta kepada negaranya.

1) Menghargai prestasi merupakan sikap dan tindakan yang mendorong dirinya untuk menghasilkan sesuatu yang berguna bagi masyarakat, dan mengakui, serta menghargai keberhasilan orang lain.

m) Bersahabat/Komunikatif. Karakter ini adalah karakter yang menunjukkan tindakan memperlihatkan rasa senang berbaicara, bergaul, dan bekerja sama dengan orang lain. Karakter ini dapat mengantar hubungan yang baik antar sesama tanpa memandang latar belakang, ras, suku, asal daerah, dan sebagainya.

n) Cinta damai merupakan sikap, perkataan, dan tindakan yang menyebabkan orang lain merasa senang dan aman atas kebajikan bagi dirinya.

o) Gemar membaca, karakter ini meliputi kebiasaan menyediakan waktu untuk membaca berbagai bacaan yang memberikan kebajikan bagi dirinya.

p) Peduli lingkungan merupakan sikap dan tindakan yang selalu berupaya mengecek kerusakan pada lingkungan alam sekitarnya dan mengembangkan upaya untuk memperbaiki kerusakan alam yang sudah terjadi.

q) Peduli sosial, karakter peduli sosial ini merupakan sikap dan tindakan yang selalu ingin memberi bantuan kepada orang lain dan masyarakat yang membutuhkan.

r) Tanggung jawab adalah sikap dan perilaku seseorang untuk melaksanakan tugas dan kewajiban yang seharusnya dia lakukan terhadap dirinya sendiri, masyarakat, lingkungan (alam, sosial, dan budaya), Negara dan Tuhan Yang Maha Esa.

\section{Urgensi Manajemen Budaya Organisasi Sekolah Terhadap Pembentukan Karakter Peserta Didik}

Budaya organisasi sekolah merupakan sekumpulan nilai yang melandasi perilaku, tradisi, kebiasaan sehari-hari, dan simbol yang dipraktikkan oleh warga sekolah seperti, kepala sekolah, pendidik, petugas tenaga 
kependidikan/administrasi, peserta didik, serta masyarakat sekitar sekolah. ${ }^{47}$

Budaya organisasi sekolah sendiri diklasifikasikan menjadi dua macam, yaitu budaya yang dapat diamati dan budaya yang tidak dapat diamati. Budaya yang dapat diamati berupa konseptual, yaitu struktural organisasi, kurikulum, behavior (perilaku), kegiatan belajar mengajar, upacara, prosedur, peraturan dan tata tertib, serta budaya yang dapat diamati berupa material seperti fasilitas dan perlengkapan. Sedangkan budaya organisasi sekolah yang tidak dapat diamati berupa filosofi yaitu visi, misi serta nilai-nilai yang berupa kualitas, efektivitas, keadilan, pemberdayaan dan kedisiplinan. ${ }^{48}$

Melalui penerapan budaya organisasi sekolah setiap hari, tentu sudah menjadi kebiasaan dan pedoman yang akan melekat dalam diri warga sekolah, baik itu budaya organisasi sekolah yang baik maupun budaya organisasi sekolah yang buruk, termasuk budaya sekolah dalam membentuk karakter peserta didik. Budaya sekolah yang baik tentu akan membentuk karakter peserta didik yang baik pula, begitupun sebaliknya.

Namun, untuk menciptakan budaya organisasi sekolah yang baik, bukan hal mudah sehingga akan terlaksana sesuai yang diharapkan. Semua perlu melalui proses, meskipun banyak faktor pendukung yang dapat membantu pelaksanaan budaya organisasi sekolah dalam pembentukan karakter peserta didik, tetapi adapula faktor penghambat yang akan menyebabkan budaya organisasi sekolah tidak dapat terlaksana dengan baik.

Pendidik menjadi faktor yang paling menentukan berhasil tidaknya program pembentukan karakter di sekolah, karena tugas seorang pendidik tidak sekedar memberikan atau mentransfer ilmu pengetahuan saja, tetapi juga mencakup pembentukan kepribadian dan karakter peserta didik. ${ }^{49}$ Seorang pendidik yang berkualitas dan benar-benar sadar akan hal tersebut, akan menjadi faktor pendukung pelaksanaan budaya sekolah dalam pembentukan karakter peserta didik. Tetapi apabila pendidik tidak profesional dan tidak mau menyadari hal itu, malah akan menjadi faktor penghambat terlaksananya budaya sekolah yang telah diinginkan.

Selain pendidik, warga sekolah lainnya dan komponen- komponen yang ada di sekolah juga tidak kalah berperannya dalam hal tersebut. Maka dari itu perlu adanya manajemen budaya organisasi sekolah termasuk dalam

47 Dewi Junita Manurung, Irawan Suntoro \& Hermi Yanzi ializa, “Pengaruh Budaya Sekolah dan Lingkungan Sekolah Terhadap Pembentukan Karakter Siswa di SMP” (No.12, Vol. 5, 2018), 3.

48 Ibid., 4.

49 Muhammad Iqbal, Niswaton \& Sakdiah Ibrahim, "Budaya Organisasi Sekolah Dalam Pembentukan Karakter Peserta Didik Pada SMA Negeri 1 Kota Lhokseumawe" dalam Magister Administrasi Pendidikan Pascasarjana Universitas Syiah Kuala (No. 4, Vol. 6, November 2018), 236. 
pembentukan karakter peserta didik. Manajemen budaya organisasi sekolah merupakan suatu rangkaian sistematis yang berfungsi sebagai perencanaan, pengorganisasian, penggerakan, pengawasan serta pengevaluasian suatu budaya organisasi sekolah yang sudah ada maupun membentuk suatu budaya organisasi sekolah baru.

Implementasi budaya organisasi sekolah takkan berjalan maksimal apabila sebuah sekolah memiliki budaya organisasi sekolah yang baik tetapi kurang dalam implementasi manajemennya. Misalnya ketika ingin membentuk karakter disiplin dalam kerapihan memakai seragam, namun tidak ada petugas yang bertanggung jawab untuk memeriksa kerapihan dan kelengkapan seragam. Atau meski sudah ada petugas yang bertanggung jawab dalam memeriksa kerapihan dan kelengkapan seragam namun tidak ada sanksi atau peraturan yang kuat bagi peserta didik yang melanggar. Hal tersebut akan membuat proses pembentukan karakter peserta didik tidak dapat terlaksana dengan baik.

Dengan adanya manajemen budaya organisasi sekolah, diharapkan budaya sekolah dapat terencana dan terkoordinir dengan baik dan rapi, faktor pendukung yang ada pada lembaga pendidikan/sekolah dapat dimaksimalkan, segala hambatan dapat ditangani dan ditemukan solusinya, serta dapat dilakukan pengevaluasian apakah harus ada pembenahan manajemen ataupun malah pembentukan budaya sekolah yang baru untuk dapat sukses membentuk karakter peserta didik sesuai tujuan yang diharapkan.

\section{KESIMPULAN}

Setiap sekolah harus mempunyai visi dan misi sebagai langkah untuk menciptakan budaya organisasi sekolah. Namun yang sering dilupakan adalah bahwa setiap sekolah telah memiliki budaya organisasi yang di dalamnya terdapat seperangkat nilai-nilai, kepercayaan, dan kebiasaan yang sudah mendarah daging. Sehingga peningkatan kualitas sekolah atau mutu pendidikan secara konvensional selama ini senantiasa bertumpu pada manajemen peningkatan kualitas proses belajar mengajar serta manajemen dalam aspek kepemimpinannya saja, namun kurang menyentuh pada aspek budaya organisasi sekolah. Manajemen budaya organisasi sekolah merupakan salah satu upaya untuk mengembangkan karakter positif peserta didik. Manajemen budaya organisasi sekolah dilakukan agar lingkungan sekolah dapat menjadi tempat yang kondusif bagi pengembangan karakter positif peserta didik dengan tetap memperhatikan prinsip-prinsip berkelanjutan, terpadu, konsisten, implementatif, 
dan menyenangkan. Untuk pengembangan budaya sekolah diperlukan empat tahapan yaitu perencanaan program, sosialisasi, pelaksanaan program, dan evaluasi program.

Dapat dipahami bahwa salah satu faktor utama yang menyebabkan buruknya budaya organisasi sekolah adalah rendahnya manajemen sekolah dalam pelaksanaannya. Sangat besar kemungkinan di berbagai sekolah, pada dasarnya memiliki budaya organisasi sekolah yang baik tetapi pada pelaksanaan manajemen sekolahnya kurang maksimal untuk pengembangan budaya organisasi. Misalnya sekolah ingin menerapkan budaya disiplin dalam menjaga kebersihan dengan membuang sampah pada tempatnya, tetapi sekolah tidak menyediakan tempat sampah, tentu peserta didik akan membuang sampah disembarang tempat karena belum tersediannya tempat. Ataupun jika tempat sampah telah tersedia namun tidak ada pengarahan serta konsekuensi bagi yang melanggar dalam pelaksanaan menjaga kebersihan tesebut, maka dapat dipastikan peserta didik tidak akan selalu membuang sampah pada tempatnya, dan tentu karakter disiplin yang ingin diterapkan tidak akan terlaksana dengan baik.

Kondisi tersebut terjadi karena sekolah belum memahami dan terampil dalam merencanakan, melaksanakan pengembangan, dan mengukur efektivitas pengem-bangan budaya sekolah. Maka sangatlah perlu untuk melaksanakan manajemen budaya organisasi sekolah dengan baik, terutama dalam pembentukan karakter peserta didik. Sebab, dampak yang ditimbulkan oleh buruknya implementasi manajemen budaya organisasi sekolah begitu signifikan. Maka dari itu, apabila sekolah memiliki budaya organisasi yang baik dan didukung dengan manajemen budaya organisasi yang baik, maka dampak yang dihasilkan tentu akan baik. Tetapi jika budaya organisasi sekolah yang baik namun tidak didukung oleh manajemen budaya organisasi yang baik pula maka dampak yang dihasilkan bisa baik, bisa juga tidak. Apalagi jika budaya organisasi yang dimiliki oleh sekolah buruk dan ditambah dengan manajemen budaya organisasi sekolah yang juga buruk sudah dapat dipastikan dampak yang dihasilkan tentu akan buruk. 


\section{REFERENSI}

Anto, Dwi. Budaya Sekolah di SMK Muhammadiyah 1 Playen Kabupaten Gunung Kidul Yogyakarta. Skripsi. Universitas Negeri Yogyakarta, 2013

Astuti, Albertin Dwi. Pengaruh Budaya Sekolah Terhadap Karakter Siswa Kelas X Jurusan Tata Boga SMK Negeri 3 Klaten. Skripsi. Universitas Negeri Yogyakarta, 2015.

Balitbang. Kepemimpinan Transformasional Kepala Sekolah. Jakarta, 2003.

Darwis, Amri. Metode Penelitian Pendidikan Islam: Pengembangan Ilmu Berparadigma Islam. Jakarta: PT Raja Grafindo Persada, 2014.

Daryanto dan Suryatri Darmiatun, Pendidikan Karakter di Sekolah. Yogyakarta: Gava Media, 2013.

Dr. Rohiat, M.Pd. Manajemen Sekolah. Bandung: PT. Refika Aditama, 2010.

Fattah, Nanang. Landasan Manajemen Pendidikan. Bandung: Remaja Rosdakarya, 1999.

George R. Terry dan Leslie W. Rue, Dasar - Dasar Manajemen, Jakarta: Bumi Aksara, 1992.

Gunawan, Heri. Pendidikan Karakter Konsep dan Implementasi. Bandung: Alfabeta, 2012.

Handoko, T., Manajemen, Yogyakarta: BPFE, 1998.

Hasibuan, Malayu, S.P. Manajemen Dasar, Pengertian, dan Masalah. Jakarta: Bumi Aksara, 2007

Hidayat, Komarudin. "Membangun Kultur Sekolah" dalam

Hikmat. Manajemen Pendidikan. Bandung: CV. Pustaka Setia, 2009.

Husaini Usman., Manajemen Teori Praktik \& Riset Pendidikan, Jakarta: PT Bumi Aksara, 2008.

Iqbal, Muhammad Niswaton \& Sakdiah Ibrahim. “Budaya Organisasi Sekolah Dalam Pembentukan Karakter Peserta Didik Pada SMA Negeri 1 Kota Lhokseumawe" dalam Magister Administrasi Pendidikan Pascasarjana Universitas Syiah Kuala. No. 4, Vol. 6. November 2018.

Kamus Besar Bahasa Indonesia (KBBI), https:// kbbi.web.id/budaya.html, 21 November 2019.

Koentjaraningrat. Kebudayaan Jawa. Jakarta: PN. Balai Pustaka, 1984.

Kurniawan, Syamsul. Pendidikan Karakter Konsepsi E Implementasi Secara Terpadu di Lingunkang Keluarga, Sekolah, Perguruan Tinggi \& Masyarakat. Yogyakarta: Ar-Ruzz Media: 2013 
Lutfania, Fauzah. Pembentukan Karakter Cinta Tanah Air di Sekolah Dasar Negeri Argosari 01 Jabung-Malang. Skripsi. Universitas Negeri Maulana Malik Ibrahim Malang, 2017.

Majid, Abdul dan Dian Andayani. Pendidikan Karakter Perspektif Islam. Bandung: PT. Remaja Rosdakarya, 2011.

Manurung, Dewi Junita Irawan Suntoro \& Hermi Yanzi ializa. "Pengaruh Budaya Sekolah dan Lingkungan Sekolah Terhadap Pembentukan Karakter Siswa di SMP". No.12, Vol. 5. 2018.

Margono. Metodologi Penelitian Pendidikan Komponen MKDK. Jakarta: PT. Rineka Cipta, 2009.

Maryamah, Eva. “Pengembangan Budaya Sekolah" dalam Tarbawi. No.02, Vo.2. Desember 2016.

Muhaimin, dkk. Manajemen Pendidikan, Aplikasinya dalam Penyusunan Rencana Pengembangan Sekolah/Madrasah. Jakarta: Prenada Media Group, 2009.

Mulyadi. "Pengembangan Budaya Mutu Madrasah Menurut Teori Block Ice Lewin" dalam Jurnal Psikoislamika. No.1, Vol.6. Januari 2009. Nasution. Metode Penelitian Kualitatif. Bandung: Tarsito, 2003.

Nanang Fattah., Landasan Manajemen Pendidikan, Bandung: PT Remaja Rosdakarya, 2000.

Neprializa. “Manajemen Budaya Sekolah" dalam Manajer Pendidikan. No.3, Vol. 9. Juli 2015.

Patilima, Hamid. Metode Penelitian Kualitatif. Bandung: ALFABETA, 2013. Pidarta, Made. Manajenemen Pendidikan Islam. Jakarta: Rineka Cipta, 2004. Robbins S.P. Perilaku Organisasi. Jakarta: Salemba Empat, 2002.

Rusydi, Mhd. Customer Excellence. Yogyakarta: Gosyen Publishing, 2017.

Samani, Muchlas dan Hariyanto. Konsep dan Model Pendidikan Karakter. Bandung: PT. Remaja Rosdakarya Offset, 2013.

Siagian, Sondang P. Kiat Meningkatkan Produktivitas Kerja. Jakarta: Rineka Cipta, 2002.

Siregar, Fitri Rayani. "Nilai-Nilai Budaya Sekolah dalam Pembinaan Aktivitas Keagamaan Siswa SD IT Bunayya Padangsidimpuan" dalam Jurnal Pusat Studi Gender dan Anak. No.1, Vol.1. 2017.

Sisk, Henry L. Principles of Management: a System Approach to the Management Process. England: South-Western Publishing Company, 1999. Soekanto, Soerjono. Sosiologi Suatu Pengantar. Jakarta: Rajawali, 1983. Sugiyono. Metode Penelitian Kuantitatif dan RED. Bandung: Alfabeta, 2009.

Sugiyono. Metode Penelitian Kuantitatif Kualitataif dan RED. Bandung: Alfabeta CV, 2014. 
Supardi. Sekolah Efektif: Konsep Dasar dan Praktiknya. Jakarta: Raja Grafindo Persada, 2015.

Surya. Nilai-Nilai Kehidupan. Kunigan: PGRI PD II Kuningan, 1995.

Suryana, Yaya. Metode Penelitian Manajemen Pendidikan. Bandung: CV Pustaka Setia, 2015.

Susanto, Achmad. Manajemen Peningkatan Kinerja Guru: Konsep, Strategi, dan Implementasi. Jakarta: Kencana, 2016.

Sutopo. Metodologi Penelitian kualitatif. Surakarta: UNS Press, 2006.

Sweeney, Paul D. \& Dean B. McFarlin. Organizational Behavior Solutions for Management. New York: McGraw, 2002.

Syamsu, Yusuf. Psikologi Perkembangan Anak. Bandung: Remaja Rosdakarya, 2008.

Tika, Moh. Pabundu. Budaya Organisasi dan Peningkatan Kinerja Perusahaan. Jakarta: Bumi Aksara, 2006.

Tim FKIM UMS, Manajemen Pendidikan, Surakarta: Muhammadiyah University Press, 2004.

Usman, Husaini. Manajemen, Teori, Praktik, dan Riset Pendidikan. Jakarta: Bumi Aksara, 2006.

Wardani, Naniek Sulistya. "Pengembangan Nilai-Nilai Budaya Sekolah Berkarakter" dalam Scholaria. No. 3, Vol.5. September 2015.

Yaumi, Muhammad. Pendidikan Karakter Landasasan, Pilar \& Implementasi. Jakarta: Prenadamedia Group, 2014.

Yusuf, Musfirotun. Manajemen Pendidikan Sebuah Pengantar. Yogyakarta: Andi Offset, 2005.

Zamroni. Pendidikan Demokrasi pada Masyarakat Multikultural. Yogyakarta: Gafin Kalam Utama, 2011.

Zuchdi. Pendidikan Karakter dalam Perspektif Teori dan Praktik. Yogyakarta: UNY Press, 2011 